\title{
Multilocus gene analysis reveals the presence of two phytoplasma groups in Impatiens balsamina showing flat stem and phyllody
}

\author{
Priyam Panda ${ }^{1} \cdot$ Amrita Nigam $^{1}$ - G. P. Rao ${ }^{2}$ (1)
}

Received: 30 October 2020 / Accepted: 23 January 2021 / Published online: 11 February 2021

(c) The Author(s) 2021

\begin{abstract}
Rose balsam (Impatiens balsamina) is an important ornamental species grown worldwide for its attractive flowers and also having medicinal properties. Flat stem, little leaf, and phyllody symptoms were observed in I. balsamina nurseries in Uttar Pradesh and Tripura states of India during surveys from 2018 to 2020, with an incidence from 6 to 27\%. Amplicons of $\sim 1.2 \mathrm{~kb}$ were amplified in all the tested symptomatic samples of I. balsamina using universal phytoplasma primer pairs from different surveyed locations, but not from the asymptomatic plants. Pairwise sequence comparison, phylogeny, and virtual RFLP analysis of 16S rRNA gene sequences identified the phytoplasmas as 16SrI-B subgroup strain from Tripura (Lembucherra) and 16SrII-D subgroup strain from Uttar Pradesh (Gorakhpur and Faizabad). Phytoplasma presence and identity was further confirmed by amplifying $\sec A, r p, \sec Y$, and tuf genes. This is the first report of 16SrI-B and 16SrII-D phytoplasmas detection in I. balsamina in the world.
\end{abstract}

Keywords Rose balsam $\cdot$ Aster yellows group $\cdot$ Peanut witches' broom group $\cdot 16 \mathrm{~S}$ rRNA gene $\cdot \sec A$ gene $\cdot r p$ gene $\cdot \sec Y$ gene $\cdot$ tuf gene $\cdot$ Weeds

\section{Introduction}

Impatiens balsamina L. (Fam: Balsaminaceae), commonly known as rose balsam, is cultivated throughout the world as a seasonal ornamental plant at offices, hotel premises, and social landscapes for its attractive different colour flowers (Staples and Herbst 2005). Different parts of the plant are used as traditional remedies for disease and skin problems (Meenu et al. 2015). Flower crops are affected worldwide by many biotic and abiotic stresses and the phytoplasma associated diseases are the main threats to their commercial cultivations (Bellardi et al. 2018).

Phytoplasmas are cell wall-less prokaryotic microorganisms colonizing plant phloem and insect tissues. The threat of phytoplasma diseases in the world is increasing with a high impact on crop yield, quality and economic losses (Bertaccini et al. 2014; Bertaccini and Lee 2018). In

\section{G. P. Rao}

gprao_gor@rediffmail.com

1 Discipline of Life Sciences, Indira Gandhi National Open University, New Delhi 110068, India

2 Division of Plant Pathology, ICAR-Indian Agricultural Research Institute, New Delhi 110012, India
India, six major phytoplasma groups (16SrI, 16SrII, 16SrVI, 16SrIX, 16SrXI, and 16SrXIV) have been identified associated with 34 ornamental plants including rose, chrysanthemum, phlox, petunias, marigold, gladiolus, mussaenda, straw flower, etc. (Madhupriya and Rao 2017; Taloh et al. 2020; Ranebennur et al. 2020; Rao 2021). The occurrence of $16 \mathrm{SrI}-\mathrm{D}$ and $16 \mathrm{SrV}-\mathrm{B}$ subgroups of phytoplasma in I. balsamina has been reported earlier from China (Chang et al. 2011; Li et al. 2011, 2014).

Although taxonomy based on the highly conserved $16 \mathrm{~S}$ rRNA gene has been useful for classification purposes, multilocus sequence typing (MLST) provide more detailed differentiation of phytoplasma strains (Hodgetts et al. 2008; Makarova et al. 2012; Martini et al. 2019).

In a recent survey, severe incidence of phytoplasma suspected symptoms of flat stem, little leaf, and phyllody were observed on I. balsamina plants in floral nurseries of two states (Uttar Pradesh and Tripura) of India. The present study was undertaken to identify and molecularly characterize the phytoplasmas detected in symptomatic rose balsam plants utilizing multilocus genes analysis and their sequence comparison. 


\section{Materials and methods}

Leaves were collected from three symptomatic and two asymptomatic plants of I. balsamina showing suspicious phytoplasma symptoms from floral nurseries at campus of Acharya Narendra Deva University of Agriculture and Technology (ANDUAT), Faizabad, Deen Dayal Upadhyaya University (DDUU), Gorakhpur, Uttar Pradesh State and College of Agriculture (CA), Lembucherra, Tripura state during surveys from 2018 to 2020 (Table 1). Weeds showing suspected phytoplasma symptoms in rose balsam nurseries were also collected from the same locations and analyzed to verify phytoplasma presence. The disease incidence was recorded in the field by counting the number of symptomatic rose balsam plants displaying symptoms over asymptomatic plants.

All samples were stored at $4{ }^{\circ} \mathrm{C}$ until processed for DNA extraction. Hundred milligrams of each sample were powdered in liquid nitrogen and total genomic DNA was extracted from leaf midrib and stalk tissue of the plant samples by CTAB method (Ahrens and Seemüller, 1992). The DNA was eluted in $100 \mu$ of elution buffer and kept at $-20{ }^{\circ} \mathrm{C}$ to use in PCR assays. PCR analyses were performed in a final reaction volume of $25 \mu \mathrm{l}$ containing $12.5 \mu \mathrm{l}$ of OnePCR ${ }^{\mathrm{TM}} 2 \mathrm{X}$ PCR Master Mix (GeneDireX, Taiwan), $10.5 \mu$ of nuclease-free water (Sisco Research Laboratories Pvt. Ltd., India), $0.5 \mu$ l of each forward/reverse primer $10 \mathrm{pmol} / \mu \mathrm{l}$ (final concentration $0.2 \mu \mathrm{M})$, and $1 \mu \mathrm{l}$ of DNA template $(=50 \mathrm{ng})$. Direct PCR amplification on 16S rRNA gene was performed using universal phytoplasma primer pairs P1/P7 (Deng and Hiruki 1991; Schneider et al. 1995) followed by nested primer pair R16F2n/R2 (Gundersen and Lee 1996). DNA extracted from the asymptomatic plants were used as negative controls, while DNA extracted from the sesame phyllody phytoplasma maintained on Catharanthus roseus in greenhouse (GenBank Acc. No. KC920747) was used as positive control. PCR reactions were carried out in a thermal cycler (Mastercycler, Eppendorf, Hamsburg, Germany) and the cycling protocol used was as reported (Panda et al. 2019).

Because the DNA-based classifications using 16S rRNA gene alone may be insufficient for finer differentiation of phytoplasma strains. Detection on primes amplifying nonribosomal regions, i.e., $r p$, $\sec Y$, and $t u f$ genes were also used to confirm and validate phytoplasma presence (Schneider et al. 1997; Lee et al. 2004, 2006, 2010; Martini et al. 2004; Al-Subhi et al. 2018). Moreover, universal phytoplasma specific primers for $\sec A$ gene were also used (Hodgetts et al. 2008; Bekele et al. 2011). The details of different multilocus genes primers along with their amplification products

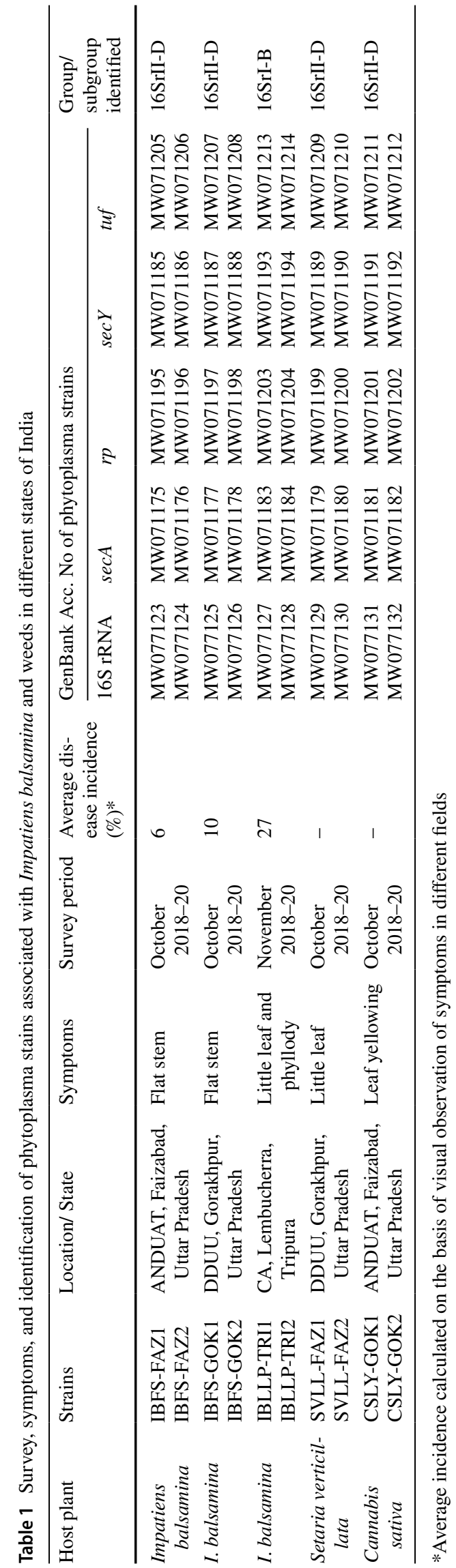


employed in the present study are listed in Supplementary Table 1.

The amplified products of the PCR assays were diluted 1:20 with nuclease free water and $2 \mu \mathrm{l}$ were used as template in nested PCR assays. Ten microlitres of nested PCR product were subjected to electrophoresis in $1.0 \%(\mathrm{w} / \mathrm{v})$ agarose gel, stained with GoodView ${ }^{\mathrm{TM}}$ Nucleic Acid stain (BR Biochem Life Sciences Pvt. Ltd., India) and observed under UV transilluminator. The amplified 16S rDNA fragments were purified using the Wizard ${ }^{\mathrm{R}}$ SV Gel and PCR Clean-up System (Promega, Madison, USA). Purified PCR products of $16 \mathrm{~S}$ rRNA, $\sec A, r p, \sec Y$, and tuf genes were ligated into $\mathrm{pGEM}^{\circledR} \mathrm{T}$ vector (Promega, Madison, USA) and cloned in competent cells of Escherichia coli (DH5$\alpha)$. The cloned products were outsourced for sequencing using M13Fwd/M13Rev universal primer pair in both directions at Eurofins Genomics India Pvt. Ltd., Bengaluru, Karnataka, India. Qiagen CLC Main workbench was used for sequence data analysis (https://digitalinsights .qiagen.com).

The sequences were assembled using DNA Base V.4 (http://www.dnabaser.com), aligned with phytoplasma ribosomal group/subgroup representatives available in GenBank using ClustalW software, and the consensus sequences were submitted to the GenBank. For ' $C a n d i-$ datus species' attribution, the 16S rRNA gene sequences were aligned with those of ' $\mathrm{Ca}$. Phytoplasma' strains, retrieved from NCBI GenBank, and the sequence identity values were determined. A phylogenetic tree was constructed using the neighbor-joining method with MEGA 7.0 (Kumar et al. 2016) using 1,000 bootstrap replications and Acholeplasma laidlawii (GenBank Acc. No. AB680603) for 16S rRNA gene and A. oculi (GenBank Acc. Nos. LK028559:1,196,113-1,198,581, L K $028559: 1,475,939-1,476,271$, L K $028559: 1,468,847-1,470,145$, LK028559:1,398,525-1,399,706) for secA, $r p$, secY, and tuf genes, respectively to root the trees.

About $\sim 1.25 \mathrm{~kb}$ of phytoplasma sequences corresponding to the R16F2n/R2 fragments of I. balsamina and weeds phytoplasma strains were subjected to in silico RFLP comparison analysis using the $i$ PhyClassifier online tool and similarity coefficient value was calculated (Zhao et al. 2009).

\section{Results}

A typical flat stem symptom was recorded on I. balsamina plants grown at floral nurseries of ANDUAT, Faizabad (IBFS-FAZ) and DDUU, Gorakhpur (IBFS-GOK), Uttar Pradesh (Fig. 1a, b) with disease incidence of $6-10 \%$ (Table 1). Moreover, little leaf and phyllody symptoms were noticed on I. balsamina plants at college campus of Lembucherra, Tripura (IBLLP-TRI) (Fig. 1c) with disease incidence up to $27 \%$ (Table 1). Setaria verticillata grown as weed in rose balsam nursery at DDUU, Gorakhpur was recorded with little leaf symptoms. Leaf yellowing symptoms were also recorded in Cannabis sativa weed grown nearby balsam nursery at ANDUAT, Faizabad.

An amplification of $\sim 1.8 \mathrm{~kb}$ and $\sim 1.25 \mathrm{~kb}$ was consistently obtained from all the nine symptomatic $I$. balsamina samples collected from Faizabad, Gorakhpur, and Lembucherra locations along with the positive controls in nested PCR assays using primer pairs P1/P7 followed by $\mathrm{R} 16 \mathrm{~F} 2 \mathrm{n} / \mathrm{R} 2$, respectively, but not in any of the asymptomatic rose balsam samples from the three places (data not shown).

Similar amplifications of phytoplasma DNA were achieved from both the collected symptomatic weed species (S. verticillata and C. sativa) (two samples each) from Gorakhpur and Faizabad, Uttar Pradesh. The sequences of the two-rose balsam phytoplasma strains from all the three locations and the two weeds were analyzed, edited, and deposited in GenBank (Table 1).

Pairwise comparison of 16S rRNA gene sequences corresponding to $\mathrm{R} 16 \mathrm{~F} 2 \mathrm{n} / \mathrm{R} 2$ fragment of rose balsam phytoplasma with the corresponding regions of different phytoplasma strains retrieved from NCBI database belongs to diverse ribosomal groups indicated that the IBLLP-TRI phytoplasma stains (GenBank Acc. Nos. MW077127-28) shared maximum nucleotide identity ranging between $99.60 \%$ and $100 \%$ with earlier reported aster yellows (16SrI) group related phytoplasma strains belonging to Zinnia elegans yellows (GenBank Acc. No. MN379838), sesame phyllody (GenBank Acc. No. KC920749) and periwinkle virescence (GenBank Acc. No. FN257484). However, IBFS-FAZ and IBFS-GOK phytoplasma strains (GenBank Acc. Nos. MW077123-26) shared 100\% sequence identity among themselves and with earlier reported peanut witches' broom (16SrII) group related phytoplasma strains reported earlier with faba bean phyllody (GenBank Acc. No. MK453522), chickpea phyllody (GenBank Acc. No. MN551487) and papaya crinkle yellow (GenBank Acc. No. Y10096). Pairwise comparison of 16S rRNA gene sequences

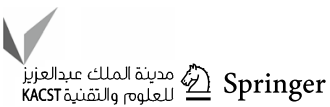


Fig. 1 Impatiens balsamina plants showing phytoplasma symptoms a flat stem at ANDUAT, Faizabad; b flat stem at DDUU, Gorakhpur, U.P.; c little leaf and phyllody at CA, Lembucherra, Tripura

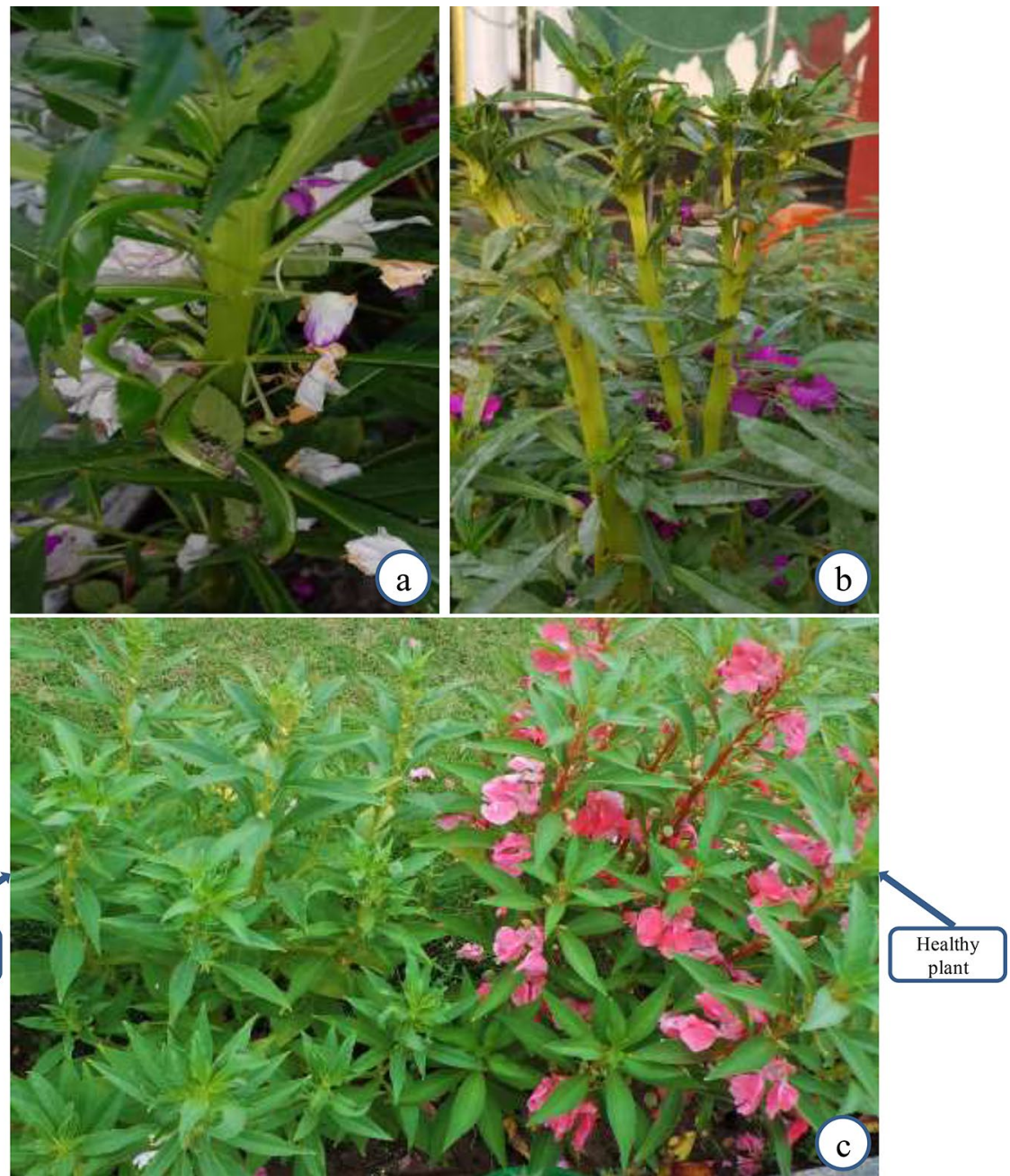

of phytoplasma strains detected in the two weed samples viz., S. verticillata little leaf (SVLL-GOK) (GenBank Acc. Nos. MW077129-30) and C. sativa leaf yellowing (CSLYFAZ) (GenBank Acc. Nos. MW077131-32) shared 100\% sequence identity with peanut witches' broom (16SrII) group related phytoplasma strains.

The pairwise comparison results were well supported by the corresponding phylogenetic sequence analysis of $16 \mathrm{~S}$ rRNA gene in which IBLLP-TRI strains clustered with 16SrI group related strains and IBFS-FAZ, IBFS-GOK, SVLLGOK, and CSLY-FAZ strains clustered with 16SrII group related strains (Fig. 2).

The PCR amplicons of $\sim 600 \mathrm{bp}$ for secA, $1200 \mathrm{bp}$ for $r p, \sim 1400 \mathrm{bp}$ for $\sec Y$, and $\sim 940 \mathrm{bp}$ for $t u f$ genes were obtained in symptomatic rose balsam plants samples from Lembucherra, Tripura by using $16 \mathrm{SrI}$ group specific primers
(Supplementary Table 1). Whereas amplicons of $\sim 600 \mathrm{bp}$ for $\sec A, \sim 1300$ bp for $r p, \sim 1700$ bp for $\sec Y$, and $\sim 1094$ bp for tuf were consistently obtained with rose balsam and weeds symptomatic samples from Faizabad and Gorakhpur using 16SrII group specific primers (Supplementary Table 1). The nested multilocus genes amplified PCR products were sequenced, analyzed, and partial secA, rp, secY, and tuf gene sequences were deposited in the GenBank database (Table 1).

Pairwise sequence comparison of $\sec A$ gene of IBLLPTRI phytoplasma stains (Table 1) was compared with different phytoplasma strains retrieved from NCBI database and showed maximum nucleotide identity of $99.4-100 \%$ with several phytoplasma classified in 16SrI group infecting sesame phyllody, periwinkle virescence, oil palm stunt, and sugarcane yellows, while IBFS-FAZ, IBFS-GOK, and 
Fig. 2 Phylogenetic tree constructed by neighbor-joining method of the partial 16S rRNA gene sequences from 16SrI and 16 SrII group of phytoplasma strains, Impatiens balsamina little leaf and phyllody (IBLLPTRI), Impatiens balsamina flat stem (IBFS-FAZ and IBFSGOK), Setaria verticillata little leaf (SVLL-GOK), and Cannabis sativa leaf yellowing (CSLY-FAZ) (red triangles). Bootstrapping was conducted 1000 times and Acholeplasma laidlawii was included as outgroup. A number on branches indicate confidence values associated with the bootstrap analysis

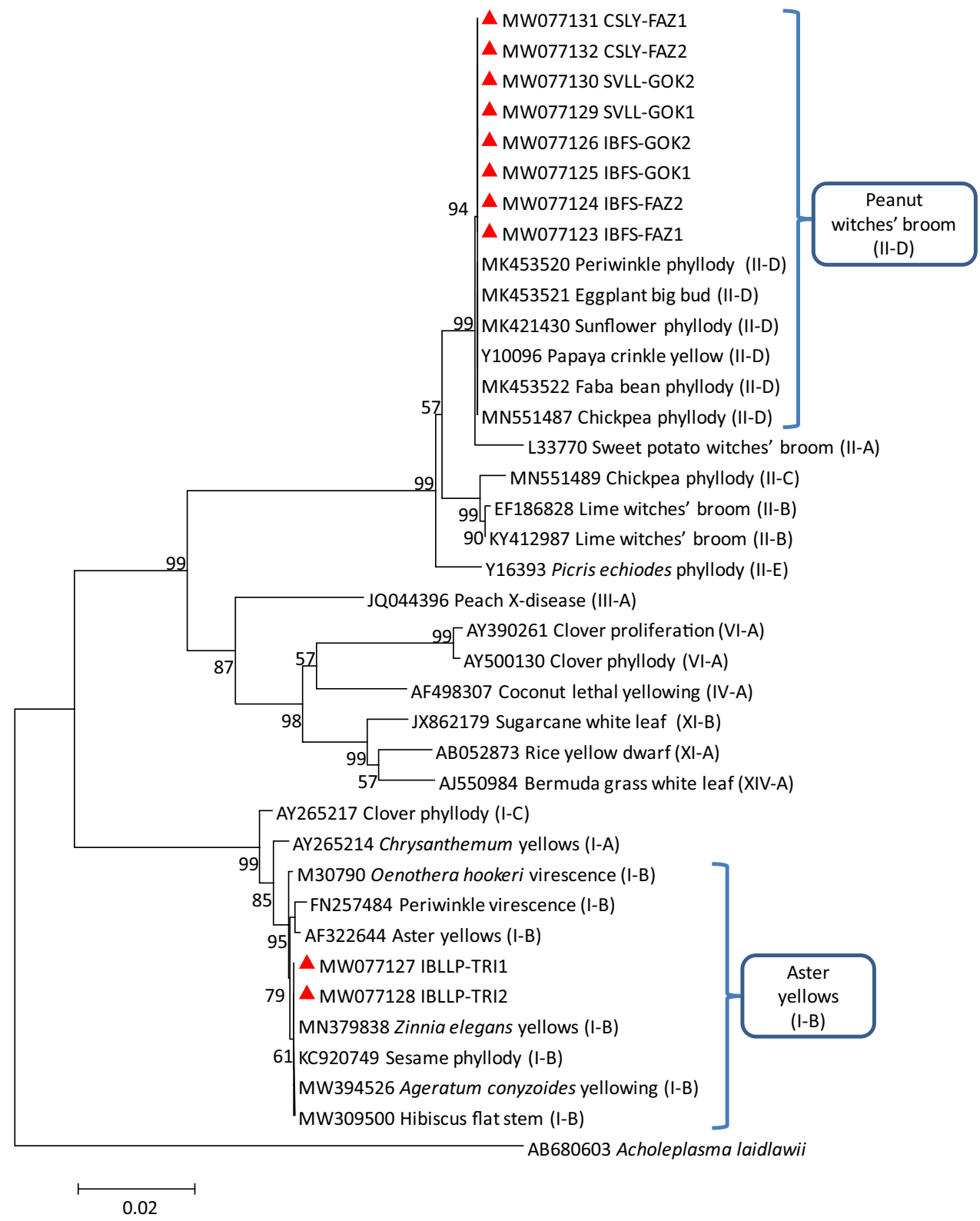

weeds phytoplasma strains (Table 1) shared $100 \%$ sequence identity with each other and 99.37-100\% identity with other previously identified phytoplasma classified in 16SrII group infecting chickpea phyllody, mango malformation, and guava leaf yellowing. Similarly, the $r p$, sec $Y$, and $t u f$ gene sequences of IBLLP-TRI phytoplasma stains (Table 1) showed maximum identities ranging between $99.3 \%$ and $100 \%$ with previously reported phytoplasma strains classified in 16SrI group, while IBFS-FAZ, IBFS-GOK, and weeds phytoplasma strains (Table 1) shared sequence identity ranging between $99.82 \%$ and $100 \%$ with previously identified phytoplasma strains enclosed in 16SrII group.

These results were also supported by the corresponding phylogenetic sequence analysis of $\sec A, r p, \sec Y$, and tuf genes in which IBLLP-TRI strain was clustered with $16 \mathrm{SrI}$ group related strains and IBFS-FAZ, IBFS-GOK, 
Fig. 3 Phylogenetic tree constructed by neighbor-joining method of the partial secA gene sequences from I and II group of phytoplasma strains, Impatiens balsamina little leaf and phyllody (IBLLP-TRI), Impatiens balsamina flat stem (IBFS-FAZ and IBFS-GOK), Setaria verticillata little leaf (SVLL-GOK) and Cannabis sativa leaf yellowing (CSLYFAZ) (red triangles). Accession numbers are specified in the tree and Acholeplasma oculi was used as outgroup. A number on branches are bootstraps values obtained for 1000 replicates

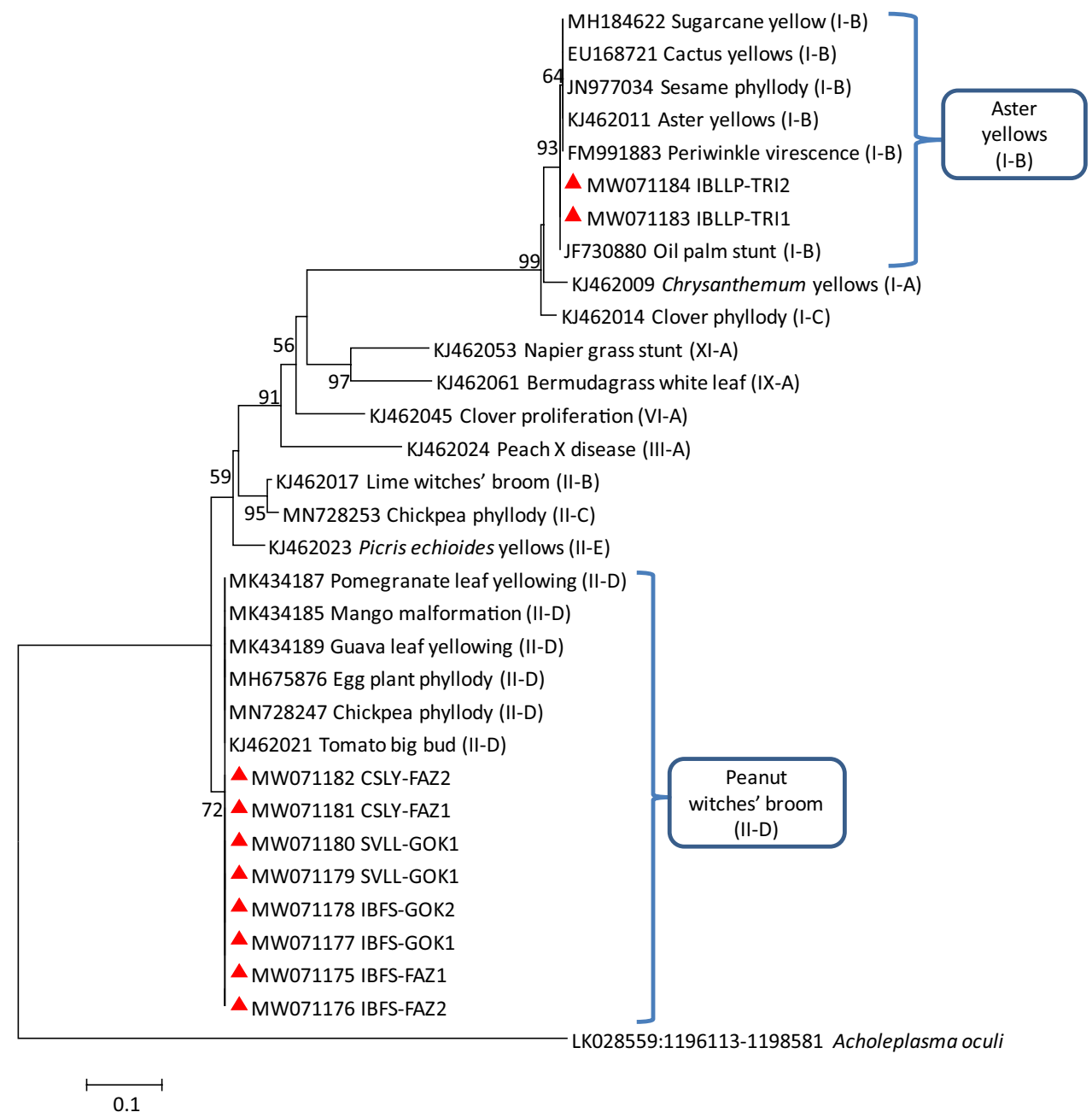

SVLL-GOK, and CSLY-FAZ strains were clustered with 16SrII group related strains (Figs. 3, 4, 5, 6).

Virtual RFLP analysis results derived from in silico digestions of $\mathrm{R} 16 \mathrm{~F} 2 \mathrm{n} / \mathrm{R} 2$ region of $16 \mathrm{~S}$ rRNA gene using 17 restriction endonucleases enzymes (AluI, BamHI, BfaI, Bst UI, DraI, EcoRI, HaeIII, HhaI, HinfI, HpaI, HpaII, KpnI, MboI, MseI, RsaI, SspI, and TaqI) indicated that IBLLP phytoplasma stains from Tripura (GenBank Acc. Nos. MW077127-28) were produced similar virtual RFLP profile identical to reference strain for 16SrI-B subgroup (GenBank Acc. No. AP006628) (Fig. 7a, b) with a similarity coefficient of 1.0. However, IBFS (GenBank Acc. Nos. MW077123-26) and two weeds (GenBank Acc. Nos. MW077129-32) phytoplasma strains from Faizabad and Gorakhpur generated restriction patterns identical to that of reference phytoplasma strain, 16SrII-D subgroup (GenBank Acc. No. Y10096) (Fig. 7c-f) with a similarity coefficient of 1.0. On the basis of similar restriction profiles, the rose balsam and weeds phytoplasma isolates in this study were classified under16SrI-B and 16SrII-D subgroups related phytoplasmas strains.

\section{Discussion}

There are thousands of $16 \mathrm{~S}$ rRNA gene sequences of phytoplasma deposited in the public databases as well as sequences to other conserved genomic regions used as supplementary tools for finer taxonomic differentiation 
Fig. 4 Phylogenetic tree constructed by neighborjoining method of the $r p$ gene sequences from I and II group of phytoplasma strains, Impatiens balsamina little leaf and phyllody (IBLLP-TRI), Impatiens balsamina flat stem (IBFS-FAZ and IBFS-GOK), Setaria verticillata little leaf (SVLL-GOK), and Cannabis sativa leaf yellowing (CSLYFAZ) (red triangles). Accession numbers are specified in the tree and Acholeplasma oculi was used as outgroup. A number on branches are bootstraps values obtained for 1000 replicates

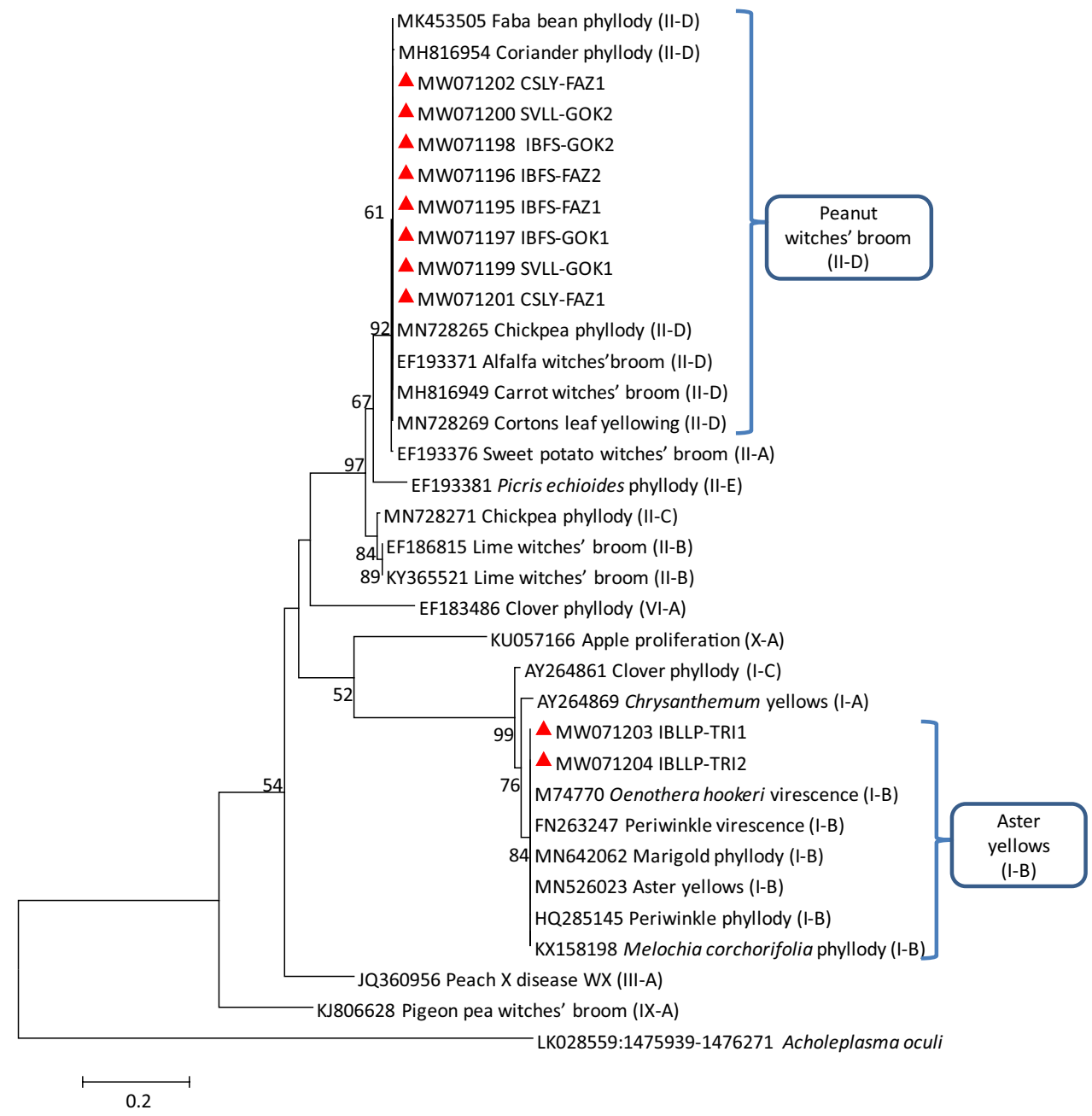

(Duduk and Bertaccini 2011). The rp, tuf, secA, and sec $Y$ genes are reported to show more variation than the 16S rRNA gene and are hence useful for the finer genetic diversity among the phytoplasma strains (Bertaccini and Lee 2018; Martini et al. 2019). Keeping this in mind, in the present study, four genes (secA, rp, secY, and $t u f$ ) other than $16 \mathrm{~S}$ rRNA were used to confirm the presence of two subgroups of phytoplasmas (16SrI-B and 16SrII-D) in symptomatic rose balsam plants and two weed samples collected from three different locations in India. The results further confirmed the validity and utility of these four genes as additional molecular markers for characterization of phytoplasma strains belonging to 16SrI-B and 16SrII-D subgroups. Multilocus genes have been successfully used earlier for finer differentiation of closely related subgroup phytoplasmas strains (Martini et al. 2007; Bohunická et al. 2018; Siampour et al. 2019). However, in the present study, all the four genes used provided similar results of grouping and subgrouping classification of rose balsam phytoplasma strains indicating that the rose balsam phytoplasma strains identified from two states of India do not have significant genetic diversity among themselves. Earlier, only two reports of occurrence of $16 \mathrm{SrI}-\mathrm{D}$ and $16 \mathrm{SrV}-\mathrm{B}$ subgroups of phytoplasmas are 
Fig. 5 Phylogenetic tree constructed by neighborjoining method of the $\sec Y$ gene sequences from I and II group of phytoplasma strains, Impatiens balsamina little leaf and phyllody (IBLLP-TRI), Impatiens balsamina flat stem (IBFS-FAZ and IBFS-GOK), Setaria verticillata little leaf (SVLL-GOK), and Cannabis sativa leaf yellowing (CSLYFAZ) (red triangles). Accession numbers are specified in the tree, and Acholeplasma oculi was used as outgroup. A number on branches are bootstraps values obtained for 1000 replicates

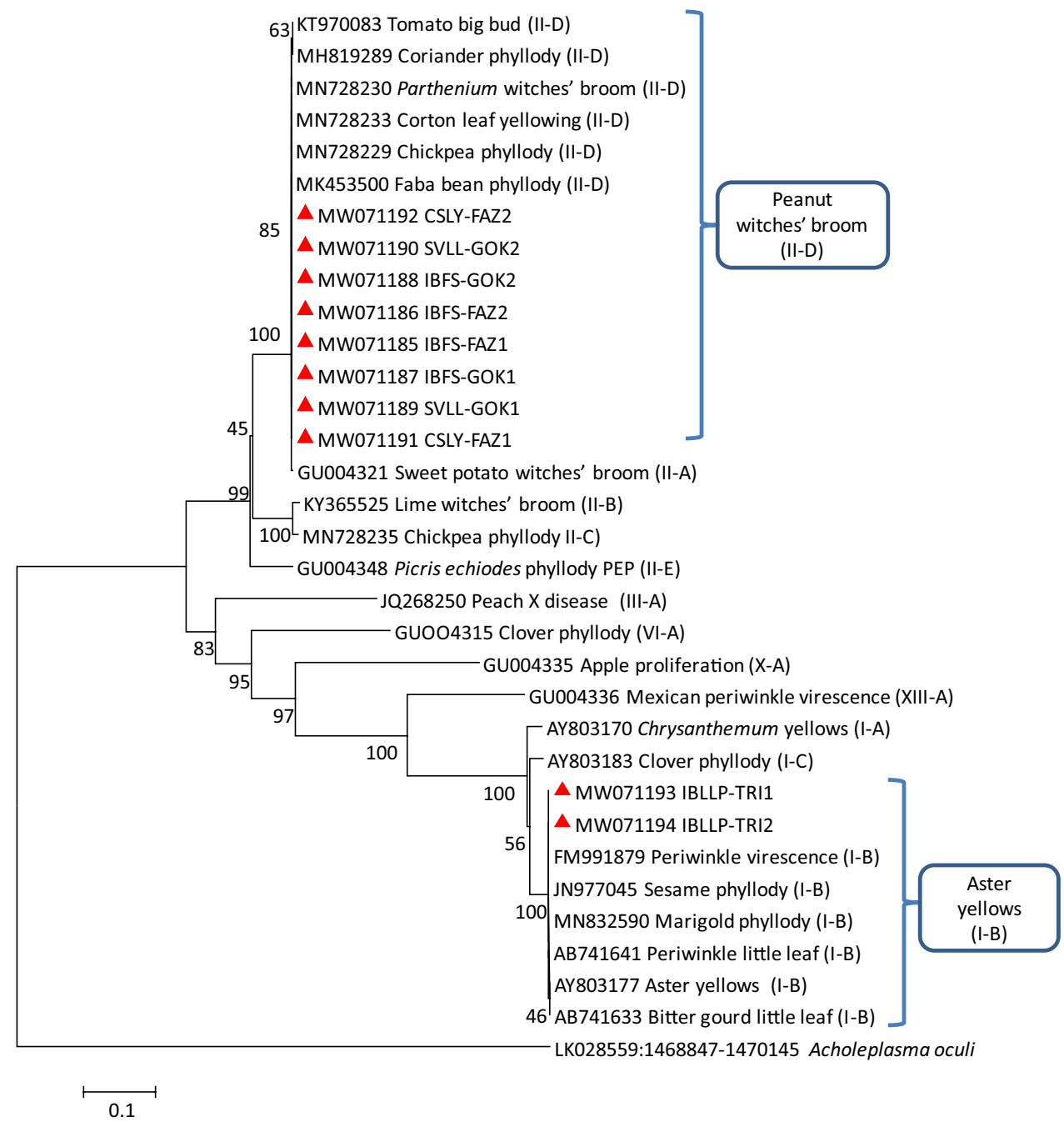

available reporting the association of phyllody and virescence disease of rose balsam from Yangling and Shandong provinces of China (Chang et al. 2011; Li et al. 2011, 2014). The present findings expand the current knowledge regarding distribution of aster yellows and peanut witches' broom related phytoplasma strains in a new agro ecosystem and report rose balsam as a new host of $16 \mathrm{SrI}-\mathrm{B}$ and 16 SrII-D subgroup of phytoplasma in the world.
The 16SrI-B and 16SrII-D subgroup, reported in rose balsam and weeds have already been reported as a major widespread phytoplasma strains infecting several important crops viz. vegetables, fruits, ornamentals, legumes, and spices in India (Kumar et al. 2017; Mitra et al. 2019; Rao et al. 2019; Panda et al. 2020; Rihne et al. 2020; Rao 2021). This study also suggested the role of $S$. verticillata and C. sativa weeds growing around the I. balsamina nurseries in Gorakhpur and Faizabad locations which 
Fig. 6 Phylogenetic tree constructed by neighborjoining method of the partial tuf gene sequences from I and II group of phytoplasma strains, Impatiens balsamina little leaf and phyllody (IBLLP-TRI), Impatiens balsamina flat stem (IBFS-FAZ and IBFS-GOK), Setaria verticillata little leaf (SVLL-GOK), and Cannabis sativa leaf yellowing (CSLYFAZ) (red triangles). Accession numbers are specified in the tree and Acholeplasma oculi was used as outgroup. A number on branches are bootstraps values obtained for 1000 replicates

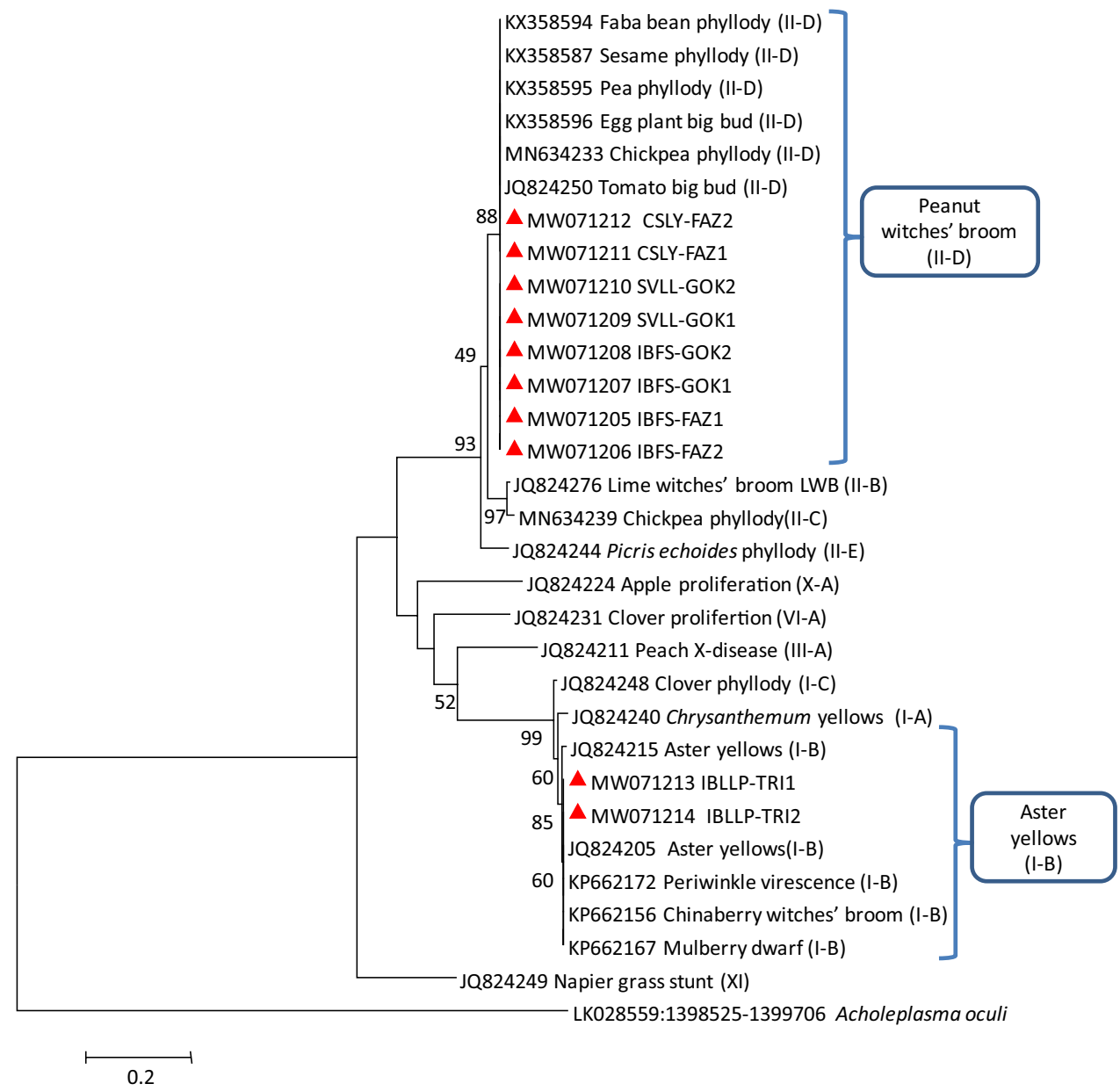

may act as a natural host reservoir for the transmission of $16 \mathrm{SrII}-\mathrm{D}$ phytoplasmas. Since the rose balsam is an important seasonal ornamental crop being grown in all parts of the country, the reported phytoplasma weed hosts may facilitate transmission of phytoplasma strains associated with rose balsam to other crops with help of leafhoppers in the country. Different species of leafhoppers
(Hishimonus phycitis, Orosius albicinctus, Amarasca bigutella, Empoasca motti) are already identified as putative or natural vectors of phytoplasma strains belonging to 16 SrI-B and II-D subgroups in India (Rao 2021) and may play significant role in transmission of rose balsam phytoplasma strains to other important agricultural crops. 
Fig. 7 Comparison of virtual RFLP patterns derived from in silico digestion of $\sim 1.25 \mathrm{~kb} 16 \mathrm{~S}$ rRNA gene sequences of reference phytoplasmas subgroup with 17 different restriction endonucleases using iphyclassifier programme, a $16 \mathrm{SrI}-\mathrm{B}$ reference strain (GenBank Acc. No. M30790), b Impatiens balsamina little leaf and phyllody (IBLLP-TRI1), c 16SrII-D reference strain (GenBank Acc. No. Y10096), d Impatiens balsamina flat stem (IBFS-FAZ1 and IBFS-GOK1), e Setaria verticillata little leaf strain (SVLL-GOK1), and f Cannabis sativa leaf yellowing (CSLYFAZ1)
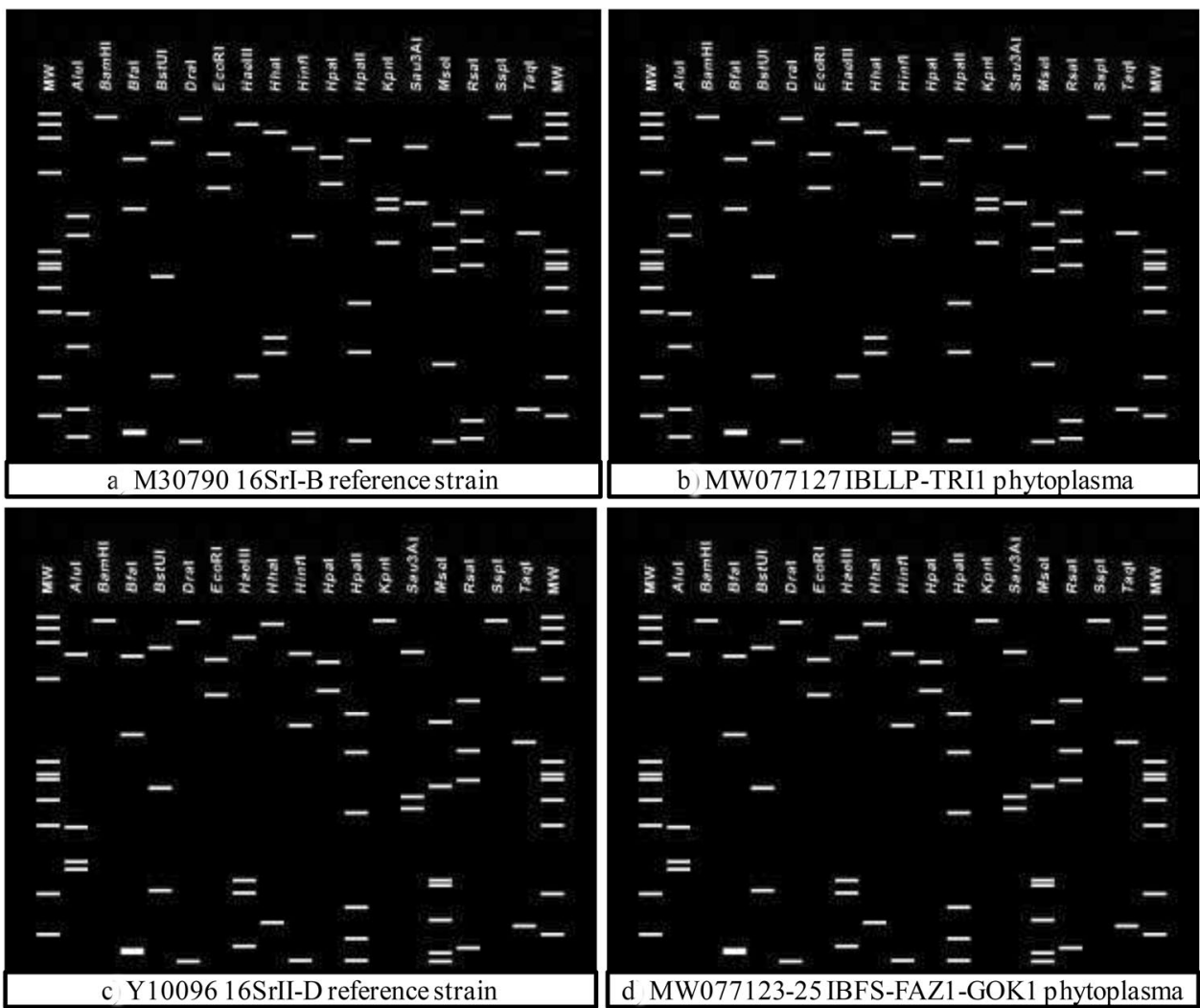

d MW077123-25 IBFS-FAZ1-GOK1 phytoplasma
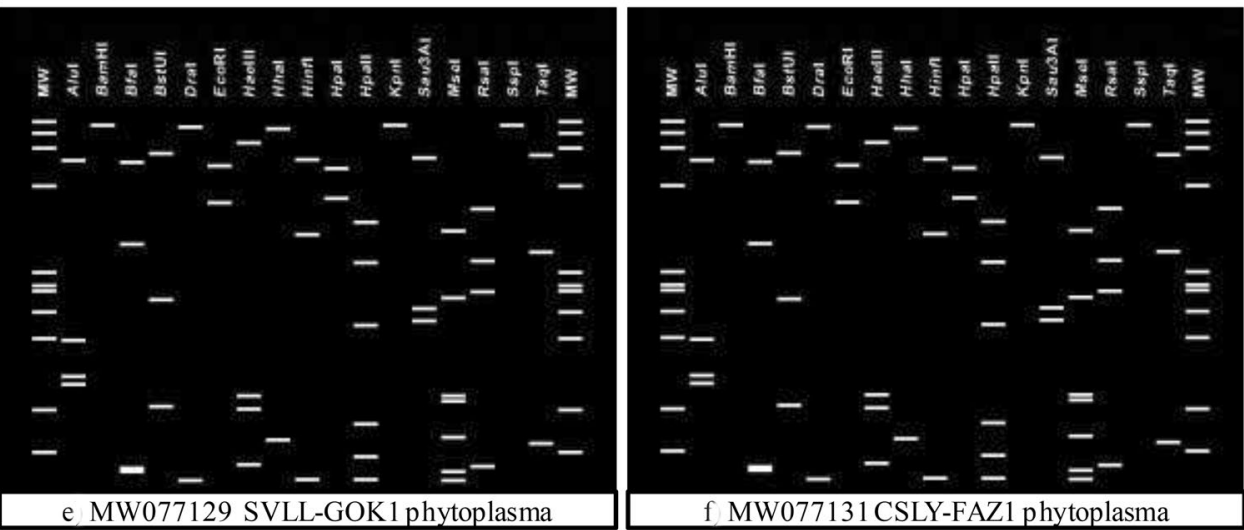

The scenario of wider natural spread of phytoplasma strains 16SrI-B and 16SrII-D infecting several crop species in India may pose a serious threat for other agriculturally important plants grown nearby rose balsam flower nurseries and thus have a great epidemiological significance. Further investigations are required to know the major insect vectors and weed species involved in the natural propagation of these phytoplasma strains to develop suitable control measures.

Supplementary Information The online version contains supplementary material available at https://doi.org/10.1007/s13205-021-02666-2.
Acknowledgements The authors wish to thank Prof Sushil Singh, Head, Department of Plant Pathology, ANDUAT, Faizabad and Dr Smriti Mall, Department of Botany, DDU University, Gorakhpur, Uttar Pradesh for their generous helps in collection of symptomatic/healthy rose balsam and weed samples from Faizabad and Gorakhpur, respectively. Authors are also grateful to Head, Division of Plant Pathology, IARI, New Delhi for proving lab facilities.

Author contributions PP contributed in analyzing the samples through PCR, sequence editing and bioinformatics analysis and preparing of ms draft. AN and GPR helped in editing and revising the text. 


\section{Compliance with ethical standards}

Conflict of interest No conflict of interest.

Open Access This article is licensed under a Creative Commons Attribution 4.0 International License, which permits use, sharing, adaptation, distribution and reproduction in any medium or format, as long as you give appropriate credit to the original author(s) and the source, provide a link to the Creative Commons licence, and indicate if changes were made. The images or other third party material in this article are included in the article's Creative Commons licence, unless indicated otherwise in a credit line to the material. If material is not included in the article's Creative Commons licence and your intended use is not permitted by statutory regulation or exceeds the permitted use, you will need to obtain permission directly from the copyright holder. To view a copy of this licence, visit http://creativecommons.org/licenses/by/4.0/.

\section{References}

Ahrens U, Seemüller E (1992) Detection of DNA of plant pathogenic mycoplasma like organisms by a polymerase chain reaction that amplifies a sequence of the $16 \mathrm{~S}$ rRNA gene. Phytopathology $82: 828-832$

Al-Subhi AM, Hogenhout SA, Al-Yahyai RA, Al-Sadi AM (2018) Detection, identification and molecular characterization of the 16SrII-D phytoplasmas infecting vegetable and field crops in Oman. Pl Dis 102:576-588

Bekele B, Hodgetts J, Tomlinson J, Boonham N, Nikolić P, Swarbrick P, Dickinson M (2011) Use of a real-time LAMP isothermal assay for detecting 16SrII and XII phytoplasmas in fruit and weeds of the Ethiopian Rift Valley. Pl Pathol 60(2):345-355

Bellardi MG, Betaccini A, Madhupriya, Rao GP (2018) Phytoplasma disease in ornamental crops. In: Rao GP, Bertaccini A, Fiore N, Liefting LW (eds) Phytoplasmas: plant pathogenic bacteria-I, characterization and epidemiology of phytoplasma-associated diseases. Springer, Singapore, pp 191-234

Bertaccini A, Lee I-M (2018) Phytoplasma: An Update. In: Rao GP, Bertaccini A, Fiore N, Liefting LW (eds) Phytoplasmas: plant pathogenic bacteria-I, characterisation and epidemiology of phytoplasma-associated diseases. Springer, Singapore, pp 1-29

Bertaccini A, Duduk B, Paltrinieri S, Contaldo N (2014) Phytoplasmas and phytoplasma diseases: a severe threat to agriculture. Am J Pl Sci 5(12):46-62

Bohunická M, Valentová L, Suchá J, Nečas T, Eichmeier A, Kiss T, Cmejla R (2018) Identification of 17 'Candidatus Phytoplasma pyri' genotypes based on the diversity of the imp gene sequence. Pl Pathol 67:971-977

Chang WC, Yuan CY, Wang XQ, Zhu XP, Li XD (2011) First report of 'Candidatus Phytoplasma asteris' associated with balsamine virescence in China. J Pl Pathol 93

Deng S, Hiruki C (1991) Amplification of 16S rRNA genes from culturable and nonculturable mollicutes. J Microbiol Methods 14(1):53-61

Duduk B, Bertaccini A (2011) Phytoplasma classification: taxonomy based on $16 \mathrm{~S}$ ribosomal gene, is it enough. Phytopathogenic Mollicutes 1(1):3-13

Gundersen DE, Lee I-M (1996) Ultrasensitive detection of phytoplasmas by nested-PCR assays using two universal primer pairs. Phytopathol Mediterr 35:144-151

Hodgetts J, Boonham N, Mumford R, Harrison N, Dickinson M (2008) Phytoplasma phylogenetics based on analysis of secA and $23 \mathrm{~S}$ rRNA gene sequences for improved resolution of candidate species of Candidatus Phytoplasma. Int J Syst Evol Microbiol 58:1826-1837

Kumar M, Madhupriya, Rao GP (2017) Molecular characterization, vector identification and sources of phytoplasmas associated with brinjal little leaf disease in India. 3 Biotech 7(1): 7

Kumar S, Stecher G, Tamura K (2016) MEGA7: molecular evolutionary genetics analysis version 7.0 for bigger datasets. Mol Biol Evol 33:1870-1874

Lee I-M, Gundersen-Rindal DE, Davis RE, Bottner KD, Marcone C, Seemüller E (2004) 'Candidatus Phytoplasma asteris', a novel phytoplasma taxon associated with aster yellows and related diseases. Int J Syst Evol Microbiol 54(4):1037-1048

Lee I-M, Zhao Y, Bottner KD (2006) SecY gene sequence analysis for finer differentiation of diverse strains in the aster yellows phytoplasma group. Mol Cell Probes 20:87-91

Lee I-M, Bottner-Parker KD, Zhao Y, Davis RE, Harrison NA (2010) Phylogenetic analysis and delineation of phytoplasmas based on sec $Y$ gene sequences. Int J Syst Evol Microbiol 60(12):2887-2897

Li Z, Zhang L, Liu P, Bai Y, Wu Y (2011) First report of an aster yellows phytoplasma as the cause of rose balsam phyllody in China. J Phytopath 159:799-801

Li ZY, Hao ZM, Dong JG, Wu D, Cao ZY (2014) First report of elm yellows subgroup $16 \mathrm{SrV}-\mathrm{B}$ phytoplasma as the cause of rose balsam phyllody in China. Pl Dis 98(4):565

Madhupriya, Rao GP (2017) Phytoplasma diseases of ornamental plants: an Indian overview. J Ornament Hortic 20:87-102

Makarova OV, Contaldo N, Paltrinieri S, Kawube G, Bertaccini A, Nicolaisen M (2012) DNA barcoding for universal identification of 'Candidatus Phytoplasmas' using a fragment of the elongation factor Tu gene. PLoS ONE 7:e52092

Martini M, Lee I, Zhao Y, Botti S, Bertaccini A, Carraro L, Marcone C, Osler R (2004) Ribosomal protein gene-based phylogeny: a basis for phytoplasma classification. IOM 11:156

Martini M, Lee I-M, Bottner KD, Zhao Y, Botti S, Bertaccini A, Harrison NA, Carraro L, Marcone C, Khan AJ, Osler R (2007) Ribosomal protein gene-based phylogeny for finer differentiation and classification of phytoplasmas. Int J Syst Evol Microbiol 57:2037-2051

Martini M, Quaglino F, Bertaccini A (2019) Multilocus genetic characterization of phytoplasma. In: Bertaccini A, Oshima K, Kube M, Rao GP (eds) Phytoplasmas: plant pathogenic bacteria-III, genomics, host pathogen interactions and diagnosis. Springer, Singapore, pp 161-200

Meenu B, Neeraja ED, Greeshma R, Alexeyena V (2015) Impatiens balsamina: an overview. J Chem Pharm Res 7(9):16-21

Mitra S, Debnath P, Bahadur A, Chandra Das S, Yadav A, Rao GP (2019) First report on 'Candidatus Phytoplasma asteris' (16SrI-B subgroup) strain associated with pineapple shoot proliferation and witches' broom symptoms in Tripura, India. Pl Dis 103(11):2941

Panda P, Nigam A, Rao GP (2019) Multilocus gene characterization of phytoplasmas in 16SrII-D subgroup associated with Coreopsis grandiflora little leaf disease in India. Phytopathogenic Mollicutes 9(2):295-301

Panda P, Rihne T, Singh AK, Rao GP (2020) Mussaenda erythrophylla: a new host of 'Candidatus Phytoplasma asteris' in India. Indian Phytopath 73(4):781-785

Ranebennur H, Rihne T, Rao GP (2020) Detection of a 'Candidatus phytoplasma trifolii'-related strain in Xerochrysumbracteatum showing a leaf yellowing disease. Phytopathogenic Mollicutes 10(1):96-99

Rao GP (2021) Our understanding about phytoplasma research scenario in India. Indian Phytopath. https://doi.org/10.1007/s4236 0-020-00303-1

Rao GP, Panda P, Reddy MG, Mishra S (2019) Identification and management of 16SrII-D phytoplasmas in cluster bean and sesame

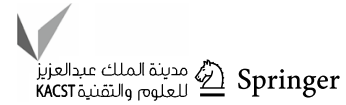


crops in the Haryana province of India. Phytopathogenic Mollicutes 9(1): 175-176

Rihne T, Mitra S, Bahadur A, Panda P, Banyal N, Rao GP (2020) Mixed infection of phytoplasma and begomovirusassociated with leaf curling and witches' broom disease of Zinnia elegans in India. Indian Phytopath 73:527-532

Schneider B, Seemüller E, Smart CD, Kirkpatrick BC (1995) Phylogenetic classification of plant pathogenic mycoplasma-like organisms or phytoplasmas. In: Razin S, Tully JG (eds) Molecular and diagnostic procedures in mycoplasmology, vol 1. Academic Press, San Diego, pp 369-380

Schneider B, Gibb KS, Seemüller E (1997) Sequence and RFLP analysis of the elongation factor Tu gene used in differentiation and classification of phytoplasmas. Microbiology 143:3381-3389

Siampour M, Izadpanah K, Martini M, Salehi M (2019) Multilocus sequence analysis of phytoplasma strains of $16 \mathrm{SrII}$ group in
Iran and their comparison with related strains. Ann Appl Biol 175(1):83-97

Staples GW, Herbst DR (2005) A tropical garden flora: plants cultivated in the Hawaiian islands and other tropical Places. Bishop Museum Press, Honolulu, USA, p 908

Taloh A, Raju DVS, Banyal N, Kumar G, Panda P, Manimekalai R, Marcone C, Rao GP (2020) Genetic diversity of phytoplasma strains infecting chrysanthemum varieties in India and their possible natural reservoirs. 3 Biotech 10(9):1-13

Zhao Y, Wei W, Lee M, Shao J, Suo X, Davis RE (2009) Construction of an interactive online phytoplasma classification tool, iPhyClassifier, and its application in analysis of the peach X-disease phytoplasma group (16SrIII). Int J Syst Evol Microbiol 59:2582-2593 